\title{
The Ottoman Response to Laurence Oliphant's Project of Jewish Settlement in Palestine (I879-I882)
}

\author{
S.. Tufan Buzpinar*
}

Laurence Oliphant’n Filistin'e Yahudi İkânı Projesine Osmanlı Cevabı (1879-1882)

Öz — Bu makale, Laurence Oliphant'ın 1879-1882 yılları arasında Filistin'e Yahudi iskânı projesiyle ilgili girişimlerini ve Osmanlı Devleti'nin bunlara cevabını incelemektedir. Oliphant'ın Filistin'e Yahudi iskânı projesiyle yoğun ilgisinin Hıristiyan siyonist arkaplanını açıklayıcı bilgiler verildikten sonra Mayıs 1879'da Osmanlı hükümetine sunulan proje detaylı olarak ele alınmaktadır. II. Abdülhamid döneminde ilk ve son defa olarak devletin en üst organlarında müzakere edilen projeye Osmanlı Devleti'nin yaklaşımı ve Mayıs 1880'de oluşturduğu ve özü itibariyle dönem boyunca korunan cevabı bu kısmın önemli katkılarındandır.

Makalenin devamı, Oliphant'ın 1882 yılında Filistin'e Yahudi yerleşimine izin alma çabalarının ikinci safhasına yoğunlaşmaktadır. Amerika'nın İstanbul temsilcisinin Oliphant'a desteğine rağmen Osmanlı Devleti'nin Filistin'e Yahudi yerleşimine karşı ısrarlı tavrı ve çözüm önerileri bu kısımda açıklanmaktadır.

Anahtar kelimeler: II. Abdülhamid, Laurence Oliphant, Hıristiyan Siyonizmi, Filistin'e Yahudi göçü, Filistin meslesi.

Laurence Oliphant (1829-1888) lived in a period when the restoration of Jews to Palestine was an important issue, discussed at different levels of British society. He was the only child of Sir Anthony Oliphant (1793-1859), a strict Evangelical and a well-known Scottish lawyer, who had an important position in

* İstanbul Medipol University.

I owe special thanks to Prof. Abdulrahim Abu-Husayn of American University of Beirut, Prof. Mahmoud Yazbak of Haifa University, Dr. Gül Tokay of Richmond University-the American University in London, Dr. Ayşe Başaran, Rakesh Jobanputra and librarians of Istanbul Şehir University for their invaluable contributions to this article. 
the British colonial government. In other words, Oliphant had strong connections in British government circles throughout his life and at times used these connections to achieve his ambitions. He did the same to realize his project of establishing a Jewish settlement in Palestine. Oliphant himself published his own account of this project and provided valuable information about the region in which he wished to settle the Jews. ${ }^{1}$ The available literature on this question mostly relies on this information. Hence, Oliphant's account was reformulated in different versions throughout the literature on the subject. ${ }^{2}$ The aim of this article is to shed new light on Oliphant's project of establishing a Jewish settlement in Palestine from the late 1870s onward with special emphasis on the Ottoman response to the project in particular and to the question of Jewish migration to Palestine in general. Since the question of Jewish settlement in Palestine is too wide to address in an article, this article will limit its scope to Oliphant's efforts and the following Ottoman response, mainly based on the relevant archival sources, in particular the Ottoman archives.

\section{I}

Available literature on the subject including Oliphant's memoirs suggests that Oliphant displayed his first serious signs of interest in the question of Jewish settlement in Palestine after the Treaty of Berlin in 1878. The fact that the Ottomans had suffered a heavy defeat at the 1877-78 Russo-Ottoman War seems to have triggered new initiatives regarding Jewish settlement in Palestine. Oliphant authored one of the initiatives that was mainly related to the Jews who had been suffering from Romanian and Russian oppressions. In fact during the war, it was not only the Muslims in the Balkans but also the Jews who were displaced and became refugees. Streets of Istanbul were full of refugees from the Balkans, overwhelming majority of whom were Muslims but also many Jews.

1 Laurence Oliphant, The Land of Gilead with Excursions in the Lebanon, (Edinburgh and London: William Blackwood and His Sons 1880); Margaret Oliphant, Memoir of the Life of Laurence Oliphant and of Alice Oliphant, His Wife, II, (New York: Harper \& Brothers 1891), p. $168 \mathrm{ff}$.

2 See, in particular, Philip Henderson, The Life of Laurence Oliphant, (London: Robert Hale Limited 1956), p. 203ff; Anne Taylor, Laurence Oliphant (1829-1888), (Oxford: Oxford University Press 1982), p. 190ff; Bart Casey, The Double Life of Laurence Oliphant, (New York: Posthill Press 2015), p. 181ff, and Norma Claire Moruzzi, "Strange Bedfellows: The Question of Lawrence Oliphant's Christian Zionism”, Modern Judaism, 26/1 (February 2006), pp. 55-73. 
Oliphant's interests in Russian affairs and Ottoman Russian relations dated back to the early 1850s. His book The Russian Shores of the Black Sea based on his visit to some Russian territories in 1852 was published towards the end of 1853. The book was received so well that it made four editions in less than six months. Oliphant spent a considerable amount of time in 1854 and 1855 in Crimea, Circassia, Istanbul and Trabzon, mainly concentrating on anti-Russian activities and trying to help the British and Turkish authorities in those regions. He even began learning Turkish in 1854 and during his stay in Trabzon in 1855 with Ömer Lutfi Pasha, the commander of the Turkish forces, his "Turkish improved to the point where he could tell jokes". ${ }^{3}$ Thereafter on two more occasions Oliphant visited the Ottoman territories in 1860 and 1862. Thus, well before the Russo-Ottoman War of 1877-78, Oliphant had become familiar with developments in Russia and the mistreatment of Jews on Russian territories and its neighbouring countries. ${ }^{4}$

Oliphant's teenage years in the 1830s witnessed discussions of the question of Jewish migration to Palestine at various levels in Britain. One of the strong supporters of this idea was Alexander Keith (1792-1880), Oliphant's compatriot from Scotland. Keith was well known as one of four Scottish priests who visited Palestine in 1839 and inquired about the possibility of Jewish return to that land which they believed to be prophesized in the Bible. One of the significant outcomes of this journey was Keith's book entitled The Land of Israel in which he used the slogan "a land without a people for a people without a land". ${ }^{5}$ Thereafter this slogan became popular with Christian Zionists, or to use the contemporary term, Christian Restorationists.

Oliphant had also strong connections with some members of the British Christian Restorationists (Zionists) ${ }^{6}$ of the period. He was a close friend of

3 Taylor, Laurence, p. 39. Oliphant's book The Trans-Caucasian Campaign of the Turkish Army under Omer Pasha: A Personal Narrative (Edinburgh and London: William Blackwood and His Sons 1856) was mainly based on his observations during the Turkish military operations in the Caucasus in 1855.

4 Oliphant, The Land of Gilead, p. XIV.

5 Alexander Keith, The Land of Israel According to the Covenant with Abraham, with Isaac and with Jacob, (New York: Harper and Brothers 1844), p. 43.

6 Christians who sought to see the Jews restored to the so-called Promised Land are called Restorationists. They believe that the restoration of Jews to their ancient homeland is one of the significant signs of Christ's Second Coming. Christian Restorationists can accurately 
Evelyn Ashley, who was Lord Shaftesbury's second son and Lord Palmerston's private secretary during his second term as prime minister between 1859 and 1865.7 Lord Shaftesbury (1801-1885) was one of the leading figures who wholeheartedly worked for the restoration of Jews to Palestine. He was the one who, by using his close connections with Lord Palmerston ${ }^{8}$ (1784-1865), convinced him of the idea of Jewish settlements in Palestine. Lord Palmerston, the Foreign Secretary, wrote a letter in August 1840 to Lord Ponsonby (1770-1855), the British Ambassador in Istanbul, saying that "It would be of manifest importance to the Sultan to encourage the Jews to return and to settle in Palestine because the wealth which they would bring with them would increase the recourses of the Sultan's dominions; and the Jewish people, if returning under the sanction and protection and at the invitation of the Sultan, would be a check upon any future evil designs of Mehmet Ali or his successor."

Oliphant's personal contacts were not only limited to some of the British Christian Zionists. His personal acquaintance extended to Sir Moses Montefiore (1784-1885), who was one of the well-known British Jewish philanthropists of the $19^{\text {th }}$ century. Sir Moses had visited Palestine several times from the 1820 's until 1874 and tirelessly worked for the welfare of Jews in the world in general and in Palestine in particular. He had secured the support of the Ottoman government in the 1850s and had purchased land in Palestine to establish a hospital and a school. ${ }^{10}$ In May 1857, Oliphant and Sir Moses met for the second time

be called Chriatian Zionists after the term “Zionism” was coined in the early 1890s. Lawrence J. Epstein, Zion's Call: Christian Contributions to the Origins and Development of Israel, (New York: University press of America 1984), pp. 1-5; Stephen Sizer, Christian Zionism: Road Map to Armageddon?, (Nottingham: Inter-Varsity Press 2010), pp. 17-24.

7 Taylor, Laurence, p. 17.

8 For more information on Shaftesbury's connections with Palmerston and how the former tried to use this connection for the realization of Jewish migration to Palestine, see Donald M. Lewis, The Origins of Christian Zionism: Lord Shaftesbury and Evangelical Support for a Jewish Homeland, (Cambridge: Cambridge University Press 2013), pp. 107-110; Stephen Sizer, Christian Zionism, pp. 57-58.

9 Quoted in Barbara W. Tuchman, Bible and Sword: England and Palestine from the Bronze Age to Balfour, (New York: Random House Trade Paperback Edition 2014), p. 152. For a Turkish translation of Palmerston's letter and the Ottoman response to it see, BOA, İ. MSM., 35/1006.

10 L. Loewe (ed.), Diaries of Sir Moses and Lady Montefiore, II, (Chicago: Belford-Clark Co. 1890), p. 51. 
on the way from Malta to Egypt. Oliphant was on his way to China as secretary to Lord Elgin and Montefiore was on his way to Palestine for his philanthropic activities. They had breakfast together and discussed issues related to the Holy Land. As recorded by L. Loewe, "Oliphant took a great interest in all matters relating to the Holy Land, and conversed freely with him on certain schemes which might serve to improve the condition of its inhabitants" ${ }^{11}$ Oliphant's accounts of Montefiore's efforts at the Porte to support the Jews in the Ottoman territories indicate how much he was aware of the previous developments regarding the Jews in Palestine. ${ }^{12}$ Thus there are several clear indications to support the view that Oliphant was well aware of the Jewish question in Europe and of the efforts to organize Jewish settlements in Palestine well before the 1877-78 Russo-Ottoman War.

\section{II}

Despite such a strong background on the question of Jewish settlement in Palestine, Oliphant did not display any serious public interest in the matter until 1878. 1878 was a turning point in Oliphant's life; after he had faced a serious crisis in his relationship with Thomas Lake Harris, his master since 1867 and the leader of a community called the Brotherhood of the New Life in Brocton ${ }^{13}$, New York, he decided to devote all his time and energy to the question of Jewish settlement in Palestine. With this crisis, Oliphant cut his ties with Harris and in March 1878, he decided to abandon all affiliations that kept him in New York. ${ }^{14}$ With serious problems in his private and religious life, Oliphant returned to England, where his mind was engaged with the developments in Europe, particularly with the immediate consequences of the Russo-Ottoman War of 1877-1878. It is interesting to note that, in his private letter to commander Dreyssé, Abdülhamid II's military adviser, Oliphant acknowledged that one of the reasons why he had left the United States was his idea of organizing a Jewish settlement in Palestine. ${ }^{15}$

11 Loewe (ed.), Diaries of Sir Moses, p. 64.

12 Oliphant, The Land of Gilead, pp. XVIII-XIX.

13 For more on the Brotherhood of New Life and Oliphant's activities in it see, Taylor, Laurence, pp. 112-145; Henderson, The Life, pp. 143-162.

14 For the crisis between Oliphant and Harris see, Taylor, Laurence, pp. 187-189.

15 BOA, Y. PRK. MYD, 1/47, Oliphant's letter to Dreyssé, n.d. but most probably dated in late April or in early May 1880. 
Meanwhile, the Great Powers of Europe were working hard to keep the balance of power in Europe after the Russian army had defeated the Ottoman army. The Ottoman state lost millions of acres of land and large populations and was faced with an enormous amount of debt which had already been causing a headache for the Ottomans since the mid-1870s but had mounted to a dramatic level due to war. The Treaty of Berlin (13 July 1878) officially ended the disputes caused by the war but it meant different things to different parties. ${ }^{16}$ For Oliphant, the Treaty of Berlin made it "evident that the Eastern Question was about to enter upon a new phase. It was manifest that the immediate effect of the treaty would be to render inevitable an external interference in the domestic affairs of Turkey, of a more pronounced character than had ever existed before". ${ }^{17}$ Oliphant's evaluation of the Treaty of Berlin was that it left the Ottoman state more vulnerable than ever to external interference.

Under the post-war conditions, Oliphant envisaged that two important needs could be addressed by an initiative to settle an important number of Jews in Palestine. He held that the Ottoman government was in urgent need to prove that it could actually reform an important part of its territory by its own initiative and thus claim that it could do the same for the rest of the country without the involvement of foreign intervention. In his own words, "it occurred to me that an experiment might be made on a small scale, and that an evidence might thus be afforded to the Porte of the advantages which would attend the development of a single province, however small, under conditions which should increase the revenue of the empire, add to its population and resources, secure protection of life and property, and enlist the sympathy of Europe, without in any way affecting the sovereign rights of the Sultan." ${ }^{18}$ To him this objective was to be realized by establishing a Jewish settlement in Palestine.

Oliphant shared main aspects of this project with his childhood friend, Princess Christian, ${ }^{19}$ the daughter of Queen Victoria, who addressed a letter, dated 11 November 1878, to the Prime Minister, Benjamin Disraeli, asking him to

16 For a recent publication on the Russo-Ottoman War of 1877-78, see M. Hakan Yavuz, Peter Sluglett (eds.), War and Diplomacy: The Russo-Turkish War of 1877-1878 and the Treaty of Berlin, (Salt Lake City: The University of Utah Press 2011).

17 Oliphant, The Land of Gilead, p. XIII.

18 Oliphant, The Land of Gilead, p. XIV.

19 Oliphant dedicated his main publication on the subject called The Land of Gilead to "the Princess Christian, as a mark of deep gratitude for the warm sympathy and cordial interest 
interview Oliphant on a subject in which she had deep interest. After listening to Oliphant, Disraeli directed him to formulate the project in written format and to submit it to the Foreign Office. The main idea of his letter to the Foreign Office, dated 14 November 1878, was that judging from the amount of money raised by the Palestine Exploration Fund during the last few years, it was clear that the British public was ready to support any project connected to Palestine. By taking advantage of this situation, the government could secure important political and financial ends. ${ }^{20}$ The Minister for Foreign Affairs, the Marquis of Salisbury, declined to take an official step towards the realization of Oliphant's project but encouraged him to visit Palestine and develop his ideas on the ground. In order to facilitate his journey to Syria and Palestine, Salisbury supplied him with letters of introduction addressed to the British diplomats in the region. ${ }^{21}$

Oliphant reached Beirut on 4 March 1879 and was received by the British consul general, Eldridge, who had been in the region for more than a decade and was well acquainted with local conditions. In the spring of 1879, Oliphant toured in Syria and Palestine with well-experienced guides provided by Eldridge and tried to identify lands suitable for settlement of Jewish migrants. Finding none on the west side of river Jordan, he proceeded to the east of the river and investigated lands in the towns of Ajloun, Balka and Karak. He finally selected a land between the river Jordan and the Haj route to Mecca in the Balka region. In Eldridge's words, the selected land "consists of high undulating ground ranging from two to five thousand feet above the level of sea, with an exceedingly salubrious climate, fine tracts of forest and pasture land, plentiful streams and a rich soil adapted for every form of cultivation". ${ }^{22}$

After identifying a land for his scheme, Oliphant proceeded to Damascus where he spent some time studying the details of the proposal that was going to be presented to the Porte. According to Eldridge, in Damascus Midhat Pasha, the governor general of the province of Syria, assisted Oliphant and "took great interest in his scheme and gave many valuable suggestions for presenting the plan

manifested by her Royal Highness in the author's efforts to promote Jewish colonization in Palestine".

20 Taylor, Laurence, p. 192; Henderson, The Life, p. 204.

21 Hansard Parliamentary Debates, 1881, Vol. 258, $3^{\text {rd }}$ Series, p. 248.

22 The National Archives (TNA), Foreign Office (FO), 78/2989 Eldridge to Salisbury, Beirut 14 May 1879. 
in the form most acceptable to the Turkish Government". ${ }^{23}$ Oliphant spent more than two months in the region where he met many individuals and high-ranking local officials, discussed details of his project, and tried to give its final shape before submitting it to the Porte. It appears that Eldridge and Midhat Pasha were most helpful in introducing him to the right people in Syria and Palestine as well as in strengthening the contents of his project. When Oliphant left Beirut for Istanbul on 12 May 1879, he had letters of introduction from Eldridge and Midhat Pasha to some influential people in the capital, hoping that they would facilitate his negotiations with the Porte. ${ }^{24}$

He arrived in Istanbul in May 1879 and submitted his proposal to the Porte in June of the same year strongly hoping that the Porte would welcome his proposal and appreciate its political and financial advantages for the Ottoman state. Henry Layard, the British Ambassador in Istanbul, helped him to find his way in the capital despite the fact that he had serious doubts about Oliphant's proposal and his ability to carry it out. ${ }^{25}$

Oliphant also had some friends from among British officers and journalists living in Istanbul. ${ }^{26}$ Armed with strong connections in London and Istanbul, he seems to have managed to create a strong impression on the Palace and the Porte. Hence, during his stay in Istanbul, Oliphant found opportunity to explain his proposal in person to the three Grand Viziers, Hayreddin Pasha, Ahmed Arifi Pasha and Said Pasha, all of whom served between 1879 and 1880, as well as the interior ministers of the period namely, Mehmed Kadri and Mahmud Nedim Pashas. Moreover, he held meetings with several ministers and Sava Pasha, the

23 TNA, FO, 78/2989, Eldridge to Salisbury, Beirut 14 May 1879.

24 TNA, FO, 78/2989, Eldridge to Salisbury, Beirut 14 May 1879. For a detailed account of Oliphant's journey to Syria and Palestine in March and April of 1879, see Oliphant, The Land of Gilead, passim. Oliphant wrote this book in 1879 while he was in Istanbul trying to get the Sultan's consent.

25 In his private letters to Lord Salisbury, the Foreign Secretary, Layard expressed serious doubt about Oliphant's project and had no hope that the Ottoman government would accept it. See, Layard to Lord Salisbury, Private, 19 August 1879 and 2 December 1879, in Sinan Kuneralp (ed.), The Private Letters of Sir Austen Henry Layard during His Constantinople Embassy 1877-1880, (Istanbul: The Isis Press, 2018), pp. 629, 658 respectively.

26 Oliphant had close relations with Valentine Baker and Augustus Charles Hobart-Hampden, British officers in the Ottoman army, and Edgar Whitaker and Valentine Chirol, British journalists. Hobart-Hampden, widely known as Hobart Pasha, even hosted Oliphant in his house in Istanbul for a while. Taylor, Laurence, pp. 196-197. 
Minister for Foreign Affairs in 1880, was particularly helpful in conveying Oliphant the nature of discussions in the cabinet and advising him what to do in order to convince the cabinet members of the political and financial advantages of his project. ${ }^{27}$

In his memorandum of 3 December 1879, addressed to the members of the Ottoman cabinet, Oliphant argued that foreign loans would strengthen foreign influence. The alternative for the Ottoman government was to take the money it urgently needed from the Jewish people who lived in different parts of the world that were not interested in politics. In return for large amounts of Jewish money, the Ottoman government could only offer them vast areas of land in Jerusalem because the Jewish people would not accept anything else. Since the money would come from the wealthy Jews living in America, England, France, Germany, Austria, Russia and other countries, and since the Jewish migrants in Palestine would become Ottoman subjects, foreign consuls would not be able to interfere on their behalf and there would be no room for capitulations. By doing so, the Ottoman government could prove that the capitulations could be abolished. Moreover, by permitting Jewish migration to Palestine, the Ottomans would display their compassion at a time when many Jews were being persecuted in other countries. This, in turn, would generate friendly feelings in Europe and in particular in England towards the Ottomans and the Ottoman sultan himself. ${ }^{28}$

This memorandum did not produce the desired effect as clear from the fact that Oliphant could not make any progress at the official level for months to come. To make things worse for Oliphant, in 1879 Anglo-Ottoman relations continued to deteriorate. Oliphant thought that under these conditions, Layard could not arrange an appointment with the Palace. In fact, no evidence is available to suggest that Layard had actually tried to get an appointment from the Ottoman authorities. On the contrary, he had serious reservations about Oliphant's scheme and had no expectations that the Porte would accept it. In his private letters to Lord Salisbury, he repeatedly shared his doubt about the scheme and held the view that Oliphant was losing his time. ${ }^{29}$ Meanwhile, Oliphant had the impression that the Sultan was hostile to Britain and Layard, contrary to the

27 BOA, Y.PRK. HR.,, 5/54, lef 1, Oliphant to Sava Pasha, n.d. but most probably dated in early April 1880.

28 BOA, Y.PRK. MYD., 1/47, lef. 2, dated 3 Kanunıevvel 1879.

29 Layard to Lord Salisbury, Private, 2 December 1879 and 28 January 1880 in Kuneralap (ed.), The Private Letters, pp. 658, 680. 
widespread view, had no influence on Sultan Abdülhamid. ${ }^{30}$ Layard was aware of Oliphant's negative impression about him and shared it with Lord Salisbury: "he thinks I have not given him sufficient support, and that he may consequently write to his friends somewhat bitterly against me. I have done all I could probably and prudently do for him." Layard once again made it clear that he had "great doubts as to the practicability of the scheme. If Oliphant gets his Firman, will he get his money and his Jews?" 11

Thus on 15 February 1880, Oliphant asked Odo Russel, the British Ambassador to Germany, to arrange a meeting with Bismarck to get German backing to his project. In the same letter, Oliphant misleadingly informed the ambassador that "the Turkish Cabinet had approved the scheme and all he needed was the Sultan's consent". He added that if Bismarck supports his scheme, people would see him as "the instrument in the hands of God to fulfil the prophecy" of the Second Coming of the Jesus. ${ }^{32}$ Oliphant's appeal to the German chancellor was particularly interesting in the sense that it predates the Sultan's initiative in May 1880 to get German support in the modernization efforts of the Ottoman army by three months.

Unable to receive additional support for his project, Oliphant made another attempt by writing a letter to Sava Pasha, the newly appointed minister for foreign affairs, informing him that by 9 April 1880 he would depart from Istanbul. In the same letter, Oliphant reminded Sava Pasha that as he had previously informed him, as of 10 February 1880, that his proposal had been discussed at the Ottoman cabinet to which all ministers with the exception of Mahmud Nedim Pasha, the interior minister at the time, had responded positively. In the end, however, Mahmud Nedim had also joined the ministers and had accepted the proposal. ${ }^{33}$ Whether Sava Pasha was telling the truth or trying to buy time, it is difficult to say. Layard had the impression that the Ottoman ministers "instead

30 Oliphant shared this view with Odo Russel first and reiterated it in his letter to his publisher dated 9 April 1880. Taylor, Laurence, p. 198; Margaret Oliphant, Memoir of the Life of Laurence Oliphant, II, p. 186.

31 Layard to Lord Salisbury, Private, 28 January 1880, in Kuneralp (ed), The Private Letters, p. 680.

32 Taylor, Laurence, p. 198. Oliphant spread this view at the time, which was echoed thereafter in the literature. See, Michael J. Pragai, Faith and Fulfilment: Christians and the Return to the Promised Land, (London, 1985), p. 54.

33 BOA, Y. PRK. HR. 5/54, Oliphant to Sava Pasha, n.d. 
of telling Mr. Oliphant frankly, at once, that his scheme could not be entertained, led him to believe it would be ultimately accepted". ${ }^{34}$ Be that as it may, Oliphant too was not optimistic about the future of his proposal. Therefore, he was trying to convince the minister that his proposal was first and foremost saving an Ottoman province from foreign interference, thus lessening the government's burden. Secondly, helping Jews who were well known for their networks and influence would ameliorate the Ottoman image in Europe. More importantly, Oliphant informed Sava Pasha that as long as the Sultan accepted the main articles of the proposal, i.e., the first four articles, he was prepared to negotiate contents of the remaining thirty-three articles. In the concluding part of the letter, Oliphant bluffed by stating that he would publicly ask the question of what it was that prevented the Sultan from approving a proposal which was unanimously accepted by the Ottoman cabinet. ${ }^{35}$

Interestingly, not long after Oliphant's letter to Sava Pasha, Layard managed to get an appointment to introduce Oliphant to the Sultan in April 1880. Although, he was aware of Oliphant's efforts to convince the Council of Ministers of his project, Layard admitted that right from the beginning he was under the impression that Oliphant would not be able to obtain "the imperial firman" granting him the lands in question. Layard reported to Granville, the minister for foreign affairs, that "at his [Oliphant] urgent request" he "presented him to the Sultan who received him with his usual kindness and courtesy and invited him to dinner". At the meeting, Oliphant personally explained his project to the Sultan, who frankly shared his views of the project. In Layard's words, at the meeting:

His Majesty observed that his ministers, who had examined into it, had reported to him that it was not one to which he could give his assent as it would 'create a state within a state'. Mr. Oliphant replied that His Majesty's ministers had informed him that they were unanimous in their approval of it, and that the opposition to it came from His Majesty alone. The Sultan expressed his surprise, denied the statement and requested that a full report of the communications which had passed between Mr. Oliphant and the Porte should be submitted to him. Oliphant then complained, in somewhat angry terms, of the manners in which he had been treated. ${ }^{36}$

34 TNA, FO, 78/3086 no. 493, Layard to Granville, confidential letter, Therapia 10 May 1880.

35 BOA, Y. PRK. HR. 5/54, Oliphant to Sava Pasha, n.d.

36 TNA, FO, 78/3086 no. 493, Layard to Granville, confidential letter, Therapia 10 May 1880. 
Understandably, Oliphant left Yıldız Palace with strong disappointment and anger. Lady Layard had more to say about the meeting. In her words, Oliphant "plunged boldly into the grievance of having to leave Turkey after a year's stay without having obtained his concession for bringing the Jews to settle in Palestine. The Sultan said he had wished it, but all his Ministers had been against it, at which Mr Oliphant indignantly told His Majesty that the Ministers told him His Majesty alone opposed it". As he was leaving the palace, Oliphant was very angry and "broke out in abuse of everyone and vowed vengeance with his pen". ${ }^{37}$

The next day Oliphant wrote a letter to commander Dreyssé, Abdülhamid II's military adviser, and asked him to submit it to the Sultan. After expressing his deep regret for abruptly leaving the Palace the previous night and thanking the Sultan for a precious present, Oliphant accused Sava Pasha, the minister for foreign affairs and Said Pasha, the grand vizier, of misleading him, for while they had been outwardly supporting his proposal, in reality they had not only hampered it but had put the blame on the Sultan himself. "Sava Pasha informed me at the presence of Sir Alfred Sandison [British Dragoman] that the Council of Ministers was in favour of my proposal but there would be an objection by the Sultan. When I decided to leave Istanbul, Sava Pasha asked me not to leave and moreover asked Sir Henry Layard's help. I was kept here for months in order to get His Majesty's consent". ${ }^{38}$ Oliphant continued to express his frustration at being misled and being kept in Istanbul "without any benefit". To him, this attitude was not only unfair but at the same time harmful to the Ottoman state. Considering that his proposal was still officially not refused, Oliphant concluded his letter by asserting that his proposal would be extremely beneficial for the Ottoman state and it would attract "good will and affection of the new government in England". ${ }^{39}$

In response to Oliphant's letter, Dreyssé stated on 5 May 1880 that from a meeting with the Sultan, he had the impression that his proposal would not get

37 Quoted in Taylor, Laurence, p. 198.

38 Layard supported Oliphant's assertions by stating "The Turkish ministers instead of telling him frankly that his scheme could not be entertained led him to believe that it would be ultimately accepted". See, TNA, FO, 78/3086 no. 493, Layard to Granville, confidential letter, Therapia 10 May 1880. Layard expressed similar views in his private letter to Salisbury. Layard to Salisbury, private letter, Pera, March 17, 1880 in Kuneralap (ed.), The Private Letters, p. 694.

39 BOA, Y. PRK. MYD., 1/47, lef 1, Oliphant to Dreyssé, n.d. 
a positive response. After expressing how sorry the Sultan had been for not accepting the proposal, Dreyssé conveyed the Sultan's expectations from the British cabinet not to spare any effort to help the Ottoman territories. ${ }^{40}$ In other words, Oliphant failed to impress the Sultan, neither during the meeting nor by writing a letter in which he had reiterated his main idea of creating a new administrative unit in Palestine under the strong support of the British government.

Against this background, the Sultan wanted to counteract Oliphant's claims that there had been a difference of opinion as to the acceptance of his proposal between the Council of Ministers and the Palace. Three days after Dreyssé's letter to Oliphant, on 8 May 1880, the Sultan sent Oliphant's proposal to the Council of Ministers asking them "to consider and examine carefully" and to inform him of their views about the project as soon as possible. According to the Turkish translation of the proposal, it consisted of four introductory and thirtythree supplementary articles. In the first four articles, which Oliphant did not want to negotiate, he proposed the creation of a migration centre in Palestine for Ottoman Jews of Anatolia and Rumelia as well as foreign Jews, who had been emancipated by the Treaty of Berlin. This fertile land would be populated by Jewish migrants who would be financially supported by wealthy Jews in Europe and Christian nations who would support their return to Palestine. ${ }^{41}$ With this strong support, the Jewish migrants would develop modern agriculture and local industry. For the organization of the migration and the administration of the Jews, a company would be established, which would pay for the price of the land and help the government increase its revenue by collecting taxes and other sources of income. Finally, upon the securement of foreign investment and the smooth operation of the new arrangements, it could be possible to extend reforms to other provinces. ${ }^{42}$

40 BOA, Y. PRK. MYD., 1/47, lef 3, Dreyssé to Oliphant, 5 May 1880.

41 Apparently, this implicit reference is to the Christians who believed in the prophecy of the second coming of Jesus Christ. For an examination of its origins and its influence on influential British circles in the nineteenth century see, Lewis, The Origins of Christian Zionism, passim.

42 BOA, Y.A. RES., 5/58. For an earlier assessment of this document, see my, "II. Abdülhamid Döneminin İlk Yıllarında Filistin'de Yahudi İskan Girişimleri (1879-1882), Türkiye Günlüğ̈̈, 30 (September-October 1994), pp. 58-65. For the modern Turkish transliteration of Oliphant's proposal see, Ömer Tellioğlu, Filistin’e Musevi Göçü ve Siyonizm, (İstanbul: Kitabevi Yayınları, 2015), pp. 285-290. 
In the remaining thirty-three supplementary articles, which he considered to be negotiable, Oliphant detailed his proposal that essentially included the following points: The Ottoman government would authorize the establishment of a company which would purchase a state land in the Balka sub-province in order to settle Jewish and other migrants and improve the conditions of that land. This company would be called The Ottoman Company for Settlement of Migrants in Palestine. The company would be subject to Ottoman laws and regulations and the government would be able to appoint a director and a deputy director in order to monitor its activities. It would be established within a year of its concession and its headquarters would be in Istanbul but it would retain the right to establish branches in some other capital cities. It would purchase one million acres of state land between the river Jordan and the Haj route to Mecca in Balka with the right to use its underground and ground resources. The area would be constituted as a separate administrative unit and be attached to the province of Syria. The price of an acre of land was to be decided during negotiations. The company would start a railway project from Haifa to Tiberias and then to the Dead Sea within three years of its date of concession. One kilometre of state land on each side of the railway route would be donated to the company and the remaining land beyond a one-kilometre limit on the route would be purchased at the same price. Local officials would be selected by the migrants and confirmed by the government. The company would have a representative in the Balka administration. Irrespective of their origins of nationality, all migrants would accept Ottoman citizenship and would be subject to Ottoman laws and regulations but they would be exempt from military service for the first two years. The local native population that resided in the purchased land would be subject to the company rules and regulations. However, all migrants settled within the purchased land would have their own court system and decisions taken by this court would not be sent to the court of appeal. Security and order of the community would be provided by infantry and cavalry forces chosen from among the migrants. If activities of the migrant community proved fruitful, the Ottoman government would permit their expansion to other parts of Palestine. The language of communication with Ottoman officials would be in either French or English. ${ }^{43}$

43 English version of Oliphant's proposal has not been discovered yet. The above-extended summary in English is translated from the official Ottoman translation preserved in the Ottoman archives and as such constitutes the first summary in English. See, BOA, Y. A. RES., 5/58. 


\section{Ş. TUFAN BUZPINAR}

The Council of Ministers discussed Oliphant's proposal on the day they received it, i.e., 8 May 1880. They considered the main aspect of the proposal to be the one million acres of lands in Palestine, which would be sold at a reasonable price to the The Ottoman Company for Settlement of Migrants in Palestine. Upon an assessment of the main points, the ministers unanimously decided that this proposal meant "government within a government ${ }^{44}$ (bükûmet içinde bir hükûmet)" and as such "it would involve political and administrative dangers", hence it was unacceptable. They also added that although the land of Balka was certainly in need of improvement in order to settle a new population, time had not yet come for this initiative and allowing some migrant settlements in the region would create problems for the local population. ${ }^{45}$ On the same day Said Pasha, the grand vizier, submitted the cabinet decision to the Sultan and returned all the relevant documents to the Palace. ${ }^{46}$ In return, Ali Riza Pasha, the first secretary at the Palace, informed the grand vizier on 6 Cemaziyelahir 1297/16 May 1880 that the Sultan had approved the cabinet decision regarding Oliphant's proposal and returned copies of the documents while keeping the originals at the Palace. Not surprisingly, the responsibility to respond to Oliphant was passed on to the Porte. ${ }^{47}$ The Grand vizier asked Sava Pasha to inform Oliphant about the final decision taken by the Ottoman state. ${ }^{48}$ On 5 June 1880 Sava Pasha informed Goschen, the special ambassador to the Porte, that after extensive discussions, the Council of Ministers had decided unanimously that Oliphant's proposal was unacceptable from "administrative and political" viewpoints. ${ }^{49}$

The British and Ottoman archival documents discovered up to now indicate that Oliphant had direct and indirect contacts with some members of the cabinet from June 1879 until May 1880. Oliphant's communications with his entourage and his correspondence with the Ottoman ministers converge on the

44 In Layard's report, this view was phrased as "a state within a state".

45 BOA, Y. A. RES., , 5/58, dated 29 Cemaziyelevvel 1297/ 9 May 1880. For another copy of the same decision see, Babıali Evrak Odası (BEO), Amedi Kalemi Defterlerinden Meclis-i Vükela Aynen Kayıt Defteri, no. 222, p. 130.

46 For Said Pasha's covering letter to the Sultan, see BOA, Y. A. RES., 5/58, 29 Cemaziyelevvel 1297/9 May 1880.

47 BOA, İ. MMS., 3114, 6 Cemaziyelahir 1297. For a rough copy of this document see, BOA, Y.PRK. BŞK., 3/7, 6 Cemaziyelahir 1297/16 May 1880.

48 BOA, HR.TH., 35/38/1, Said Pasha to Sava Pasha, 11 Cemaziyelahir 1297/21 May 1880.

49 BOA, HR.TH., 35/38/2, Sava Pasha to Goschen, no. 58462, 5 June 1880. For a rough copy of Sava Pasha's letter to Oliphant see, HR.TH, 35/38/3, n.d. 
point that his contacts in the Ottoman government consistently gave him hope and indicated that it was up to the Sultan whether to approve or disapprove of the government's affirmative view of the proposal. Be that as it may, the fact of the matter was that the relevant documents on the subject had nothing to support Oliphant's claims. Some ministers such as grand vizier Said Pasha and the Minister of the Interior Mahmud Nedim Pasha had serious reservations about Oliphant's proposal and it is most likely that they had shared their reservations with the Sultan before he accepted Oliphant at the Palace. In other words, Abdülhamid had been informed about Oliphant's efforts to impress the Council of Ministers regarding his scheme and had a clear idea about the project before he listened to Oliphant at the Palace.

The timing of Abdülhamid's acceptance of Layard and Oliphant at the Palace was also significant. The Sultan accepted Layard and Oliphant after the well-known anti-Turkish politician Gladstone had formed a new government in Britain and after he had decided to ask the Germans to provide him with military and civilian advisers. ${ }^{50}$ It is also interesting to note that before the meeting, he had been informed about the informal view of influential members of the cabinet about the project. Moreover, on 5 May 1880, three days before he sent all the documents regarding the proposal to the cabinet, the Sultan had sent a clear message via his military advisor Dreyssé to Oliphant that his proposal was unacceptable. ${ }^{51}$ In other words, before the cabinet discussed the proposal and formed their official view about it, Abdülhamid had made his mind up and let Oliphant know about it. What was most striking was that in his letter to Dreyssé, in an effort to reduce the Sultan's anxieties and weaken potential objection to the subject, Oliphant stated that "to prevent government within a government", the Porte had a full right to take all preventive measures. ${ }^{52}$ Strikingly, the Porte refused the proposal on 9 May 1880 on the ground that it essentially meant "government within a government", repeating what the Sultan had already told Oliphant at the Palace.

50 For Abdülhamid's approach to Germany see, Kemal Beydilli, "II. Abdülhamit Devrinde Gelen İlk Alman Askeri Heyeti Hakkında”, IÜEF Tarih Dergisi, XXXII (1979), pp. 481493; Feroze A.K. Yasamee, Ottoman Diplomacy: Abdülhamid II and the Great Powers, 18781888, (İstanbul: The Isis Press 1996), p. $73 \mathrm{ff}$.

51 BOA, Y. PRK. MYD.. 1/47 lef. 3, Dreyssé to Oliphant, 5 May 1880.

52 BOA, Y. PRK. MYD. $1 / 47$ lef. 1, Oliphant to Dreyssé, n.d. but it was dated before 5 May 1880. 
It should be pointed out that the timing of the proposal was most unfortunate for Oliphant. Throughout 1879, the Ottoman authorities were struggling to overcome the difficulties created by the Russo-Ottoman War of 1877-78. The Treaty of Berlin (June 1878) caused many problems that would have to be solved over the following years. Without going into details suffice it to say that the Russian army did not leave Ottoman territories until August 1879, the crisis with Austria, Greece and Montenegro continued at various extents until 1881, and British pressure mounted on the issue of the reforms to be implemented in Eastern Anatolia. Abdülhamid was particularly disturbed by the fact that from November 1878 onward, the British government appointed numerous military attaches in Eastern Anatolia in order to monitor Ottoman reform efforts regarding the Armenian population in that region. ${ }^{53}$

Moreover, Oliphant's project had almost coincided with serious political crisis in Istanbul as well as the crisis in Egypt. As for the political crisis in the capital, it should be mentioned that during a year of Oliphant's stay in Istanbul, three grand viziers rotated in that office..$^{54}$ Oliphant had to meet them all in trying to convince them of the importance of the project. In the same period, British and French influence in Egypt had reached such a degree that there were anti-foreign protests which paved the way for Khedive İsmail Pasha to dismiss representatives of both countries from the cabinet. This in turn led both powers to put pressure on the Sultan to depose the khedive, arguing that İsmail Pasha had not fulfilled his international financial obligations. The Sultan was hesitant in accepting the British and the French demands but the Grand Vizier, Hayreddin Pasha, supported the view that under the circumstances, deposing the khedive was the right decision to take. In a way, the Sultan was forced to depose khedive İsmail, but this incident also increased the Sultan's suspicion of Britain's designs in Ottoman Arab provinces and further deteriorated relations between the two countries. ${ }^{55}$

53 For an evaluation of the critical developments after the Congress of Berlin, see Feroze A. K. Yasamee, "European Equilibrium or Asiatic Balance of Power: The Ottoman Search for Security in the Aftermath of the Congress of Berlin" and Gül Tokay, "A Reassessment of the Macedonian Question, 1878-1908", in War and Diplomacy, pp. 56-78 and pp. 253259, respectively.

54 For the list of grand viziers served in 1879-80 see, Gökhan Çetinsaya, "II. Abdülhamid'in İç Politikası: Bir Dönemlendirme Denemesi”, Journal of Ottoman Studies, XLVII (İstanbul 2016), p. 371.

55 Yasamee, Ottoman Diplomacy, p. 70. 
In addition, the Ottoman government had to take care of hundreds of thousands of refugees, the overwhelming majority of whom were Muslims. At the time when Oliphant was trying hard to get a favourable response to his project, the streets of Istanbul were full of refugees, some of whom were sent to surrounding provinces and others sent to provinces as far away as Adana and Syria. Moreover, since July 1878, there had been several placards criticizing the Ottoman administration, thus increasing the sensitivity of the region in the eyes of the Ottoman government. Former Grand Vizier Midhat Pasha was appointed governor of Syria in November 1878 as part of an effort to enhance state authority in the region. In short, the Ottoman State was going through tough times at national and international levels, hence Oliphant's unprecedented proposal for Jewish settlements in Palestine did not receive due attention at the official level.

As for a brief assessment of the proposal, its basic assumption was that the Ottoman state was very weak in its international relations and financial affairs as well as in trying to preserve state authority over its territories in the Balkans, Eastern Anatolia and the Arab lands. Oliphant naively assumed that any state in such a vulnerable position would be willing to sell a portion of its land provided that it was not densely populated, disregarding the sensitivity of its location from domestic and international points of view. ${ }^{56}$ Moreover, the proposal envisaged an autonomous region to be governed by newly arriving mainly foreign

56 Oliphant was not alone among the British Christian Zionists who wished to make use of vulnerable position of the Ottoman state. Edward Cazalet, a British industrialist (18271883), was eager to see the expansion of British power over Syria and Palestine and attributed an important role to the Jews for the development of the region. He published two treatises (The Eastern Question, The Berlin Congress) in 1878 in which he supported the idea of Jewish settlements in Palestine as part of a development scheme, which was going to be related to the Euphrates Valley Railway Project. Cazalet was a staunch supporter of this railway project for he hoped that it would facilitate first, the British protectorate over Syria and Palestine and thus prevent Russian penetration in the region. Secondly, this railway, when it is completed, "will bring us [the British] three or four days nearer India". "With Syria under our protection the whole of this new and shorter route to India will be under our control from one end to the other". Cazalet was well aware of the heavy pressure on the Jews in Eastern Europe including Russia and hoped that Jewish settlement in Palestine would seriously contribute to the success of the railway project and ultimately to the British position in the region. Edward Cazalet, The Berlin Congress and the AngloTurkish Convention (London: Edward Stanford 1878), p. 21; Edward Cazalet, The Eastern Question (London: Edward Stanford 1878), pp. 39-40. 
migrants at a time when the Ottoman state already had deep suspicions about the intentions of the Great Powers, who were expected to support Jewish migration to Palestine and at a time when the Ottoman state suffered severely from demands for autonomy by other minorities. To add to these, it proposed that the migrants would have their own independent judicial and security systems. Last but not least, one of the important weaknesses of the proposal was that its financial aspect was based on assumptions rather than on realistic sources. Oliphant assumed that the project would be financed by wealthy Jews around the world as well as by Christian Zionists, ${ }^{57}$ a group about whom the Ottoman ruling elite, not surprisingly, knew almost nothing. It was this last point that had the greatest influence on Oliphant for some time. During his stay in Istanbul, Oliphant reiterated his belief that the restoration of Jews to Palestine was one of the signs of the second coming of Jesus Christ. He used this view to persuade Odo Russel, the British Ambassador in Berlin, saying, "If Bismarck acquiesced in the plan people would think he was the instrument in the hands of God to fulfil the prophecy and bring about the end of the world". ${ }^{58}$ In this context, Layard's remarks to one of his friends, Augusta Gregory, reflect an interesting aspect of Oliphant's efforts to convince the Ottoman authorities: "he [Oliphant] himself put a stopper on it by telling the Sultan's secretary that he was seeking to fulfil the Scripture that the end of the world was to come when the Jews were restored to their native land, and his Majesty had no desire to hurry that event". 59 It appears that right from the beginning, Oliphant believed that the whole project would essentially be financed by the Christians of the West who believed in the prophecy that restoration of the Jews to Palestine was a precondition of the second coming of Jesus Christ. ${ }^{60}$

57 In the official text of the proposal submitted to the Porte, Oliphant states that "Jewish migrants will financially be supported ...by Christian nations who support their return to Palestine" and in a private letter the wording is slightly different but the indication to Christian Zionists is clearer: "Any amount of money can be raised upon it, owing to the belief which people have that they would be fulfilling prophecy and bringing on the end of the world." Margaret Oliphant, Memoir of the Life of Laurence Oliphant, II, p. 169.

58 Taylor, Laurence, p. 198.

59 Quoted in Taylor, Laurence, p. 199.

60 Margaret Oliphant, Memoir of the Life of Laurence Oliphant, II, p. 169. 


\section{III}

Oliphant left Istanbul for London on 11 May $1880^{61}$ angry and frustrated and expectedly expressed his feelings against the Ottoman government in his articles and letters written immediately after his return from the Ottoman capital. Interestingly, he spared the Sultan from criticism and expressed his hope that Hayreddin Pasha or Midhat Pasha would take the grand vizierate, a hope that would never be realized after 1880 . While publicly criticizing the Ottoman government, privately he sent a confidential letter to a man called Münir, ${ }^{62}$ stating that in line with the Sultan's wishes, after leaving Istanbul, he had seen the King of Greece and discussed the question of borders and in London he had had discussions with leading politicians, including Gladstone, the Prime Minister, and Granville, the Foreign Secretary, about questions related to Greece and Montenegro. The final point in the letter was an irritating piece of advice to the Sultan, stating that "the most important measure to exalt the dignity of the Ottoman state was the issue of reconvening the parliament in Istanbul". ${ }^{63}$ This point also shows the degree of Oliphant's ignorance of the nature of politics in Istanbul and who was who in the period when he was trying to secure a concession from the Ottoman government.

The Ottoman rejection of Oliphant's proposal did not lead to a substantial change in his mind about the restoration of Jews to Palestine, but added a new dimension to it. Sometime after he had left Istanbul, Oliphant decided to live in Palestine during the rest of his life. ${ }^{64}$ To implement his decision, he needed some preparatory work and, more importantly, enough money to finance his settlement. From the second half of 1880 until early 1882, apart from publishing his well-known book on the subject, The Land of Gilead ${ }^{65}$, Oliphant devoted much of his time to his personal affairs and preparatory work for Palestine. Due to his and his wife's health conditions, he spent the winter of 1880-81 in Egypt ${ }^{66}$, then

61 Layard states in his report that Oliphant will leave Istanbul on 11 May. See, TNA, FO 78/3086 no. 493, Layard to Granville, 10 May 1880. There is also a note in Dreyssés letter to Oliphant stating that "Monsieur Oliphant will leave Istanbul this coming Tuesday [11 May 1880]”. BOA, Y. PRK. MYD., 1/47, lef 3, Wednesday, 5 May 1880.

62 This could either be Ahmet Münir (1828-1897) or Salih Münir (1857-1939) both subsequently became pashas.

63 BOA, Y. PRK. TKM., 3/20, Oliphant to Münir, 18 June 1880.

64 Henderson, The Life of Laurence Oliphant, p. 211.

65 Published in December 1880.

66 The Land of Khemi is on his days in Egypt. 
went to the United States, where his principal aim was to retrieve the money he handed to the Brotherhood so that he could finance his future plans concerning Palestine. After securing his money in the United States, Oliphant returned to England in late January 1882 and found himself again deeply involved in the Jewish question. During the period he had been in the States, Romanian and Russian mistreatment of the Jews had continued, as a result of which thousands of new Jewish migrants had arrived in Western Europe by January 1882. In London, various organizations initiated new activities to help the migrant Jews. One of these organizations was Mansion House, which organized a meeting on 1 February 1882 to raise money for the Jewish cause. A committee was named to administer the money. It was presided over by the well-known Christian Zionist Lord Shaftesbury and Oliphant was appointed as a member. Opinions were divided as to where the new migrant Jews were to be sent: some argued that the most suitable country was the United States, whereas Christian Zionists including Oliphant argued that these migrants should be settled in Palestine, where their religion and culture would not be in danger. On 15 February 1882, Oliphant published a letter in The Times in which he strongly argued that the dominant idea of the Eastern Jew was to return to Palestine, hence defended the view that the migrant Jews should be settled in Palestine. ${ }^{67}$ The effect of the letter was visible. He was selected as one of the Commissioners set to visit Jewish refugees in Galicia in order to assess the situation and distribute the funds raised in London. ${ }^{68}$

Oliphant left England in March 1882 for Berlin first and then for Vienna. By this time, Oliphant had already been known by Jewish leaders in Western and Eastern Europe for his colonization scheme in Palestine and was greatly respected by those that shared his Christian Zionist views. Being in utter despair, the Jews of Romania and Russia had high expectations of Oliphant because many "journals said that he was indeed a great man, a wise and sensible man, an authority". ${ }^{69}$ Against this background, in April 1882 Oliphant visited Jewish refugee camps in Brody where he, together with two other members of the Mansion House Committee, distributed funds and selected those Jews best suited to travel to the United States. Soon after, however, he resigned from this committee, believing he

67 In this long letter, Oliphant briefly mentioned his proposal of 1879 on the subject and argued that it had failed because of "special political complications". The Times, 15 February 1882.

68 Taylor, Laurence, p. 206.

69 Taylor, Laurence, p. 208. 
should devote his time and energy to the colonization of Palestine rather than in organizing Jewish migrations to the United States.

In May 1882, Oliphant went to Romania where there were many Jewish leaders who shared his view of Jewish restoration to Palestine. At the time, Romania was the key country for Oliphant's project as thousands of Romanian Jews had been forced to leave the country and were in search of a new land in which to settle. For Oliphant, Romania was also important in the sense that there existed a strong Jewish group eager to migrate to Palestine in opposition to others who wished to migrate to the United States. In the same month he attended a conference at Jassy organized by the Romanian Jews who were eager to go to Palestine. He was received with great respect and was surrounded by grateful Jews at the conference and after. Oliphant promised to present their case to the Sultan in Istanbul. To this end, he left for Istanbul via Bucharest.

In Istanbul, developments were taking place in a different context. The Ottoman state was dealing with thousands of refugees, including a small minority of Jews from the Balkans and Rumania in particular. More importantly, OttomanBritish relations had deteriorated further, principally because of the Egyptian crisis that had been deepening since protests by Egyptian officers in January 1881 . By the time Oliphant arrived in Istanbul in the summer of 1882, the crisis had reached a point where military intervention was being seriously considered in order to restore order in Egypt. ${ }^{70}$ Thus, Abdülhamid and his ministers were not in a position to discuss any other topic, especially if it came from a British subject.

Considering these developments and considering the fact that the United States had opened its doors to Jewish refugees, Oliphant judged that the best option was to approach the American diplomats in Istanbul. In early June 1882, Oliphant shared his knowledge on what had been happening to the Jews in Russia and Romania with Wallace, U.S Envoy to the Ottoman State, and drew his attention to the Romanian Jewish refugees in the streets of Istanbul. Oliphant managed to influence Wallace, who acknowledged it by saying that "my sympathy was naturally excited in their behalf". With this feeling, on 6 June 1882 Wallace received two Jews named M. Ascher and M. Weinberg as representatives of the Romanian Jewish committees at the Legation of the United States in Istanbul. After explaining the unjust treatment of the Jews in Romania, they presented

70 For an excellent treatment of the Egyptian crisis within the context of diplomatic history, see Yasamee, Ottoman Diplomacy, pp. 87-100. 
Wallace with a petition in which they essentially wished to know "whether the Jews on becoming Turkish subjects will be permitted to settle in the waste lands of the Vilayet of Syria excluding the Pashalik of Palestine free of charge in groups of not more than five hundred families, and whether they will also be permitted to purchase lands and settle on them in agricultural communities." ${ }^{71}$ At the meeting, Wallace promised them he would convey their message to the Ottoman authorities.

On 12 June 1882 Wallace visited Said Pasha, the Grand Vizier, and expressed his personal interest in the question of Jewish refugees. After making it clear that his connection with this question was unofficial, Wallace asked the grand vizier whether the Sultan and the Porte would allow Jewish refugees to come to the Ottoman territories. Wallace was assured that the question had been before the Council of Ministers, which had decided that:

the Jews from whatever parts could come and settle in Turkey [sic]; that there was a general law of immigration in force which must be taken for the guidance of such as chose to come; that they could come when they pleased, and would be settled in groups of two hundred or two hundred and fifty families, that they could settle on any unoccupied lands in Mesopotamia, about Aleppo, or in the regions of the Orontes River; that they could not establish themselves in Palestine; that the firman of the Sultan was unnecessary, for, having once approved the law, he could not be called on to do so again; that every colonist was simply bound to become an Ottoman subject. ${ }^{72}$

It appears that the Porte's answer was based on subtle calculations. First, by welcoming all migrants, including Jews, the Porte was trying to compensate for the millions lost during the 1877-78 Russo-Ottoman War. Secondly, by settling the migrants in state wastelands within a proper program, the Porte wished to improve agricultural production in areas where the state had firm control. Thirdly, by welcoming the Jewish migrants on its own terms at a time when hundreds of thousands of them were being persecuted in Romania and Russia, the Porte

71 Ascher and Weinberg to Wallace, Constantinople, 6 June 1882 enclosure no. 1 in 107, Wallace to Frelinghuysen, 11 July 1882, in Papers Relating to the Foreign Relations of the United States, December 4, 1882, Washington: Government Printing Office 1883, p. 517-18.

72 Wallace to Frelinghuysen, Constantinople, no. 107, 11 July 1882, in Papers Relating to, p. 517. 
aimed to increase its prestige, at least in the eyes of such states as the United States. Finally, the Porte maintained its position regarding its ban on Jewish migration to Palestine and its last response included a clear message to the effect that because of its proximity, Jewish migrants would not be allowed to settle in the province of Syria, either.

Be that as it may, Wallace was satisfied with the Porte's answer and pleased that apart from the territories of Syria and Palestine, Jewish migrants were welcomed to the Ottoman State in order to settle, especially in Anatolia. To him, the Ottoman law of immigration was "liberal and encouraging; if they behaved themselves they would do well." Thus he concluded his report by stating that, "there is nothing to prevent all the Israelites on the earth from settling in Asiatic Turkey. They shall not settle in Palestine-that is the only prohibition". ${ }^{73} \mathrm{He}$ reported on what went between himself and the Porte regarding the Jewish migration to Oliphant and the two Romanian Jewish representatives who had visited him earlier at the Legation of the United States. Having provided a copy of the Ottoman law of immigration in English, Wallace informed Oliphant and his associates that he had fulfilled his mission and as far as he was concerned, nothing more could be demanded from the Ottoman government.

As for the key articles of the Ottoman law of immigration, it stipulated that all the migrants would become Ottoman subjects without any reservation or restrictions; that "they will enjoy without any distinction the same religious privileges as all the other classes of subjects of the empire"; that they will be settled by the government on state lands; that they "will be exempt from all land and personal taxation for six years, if they are established in Rumelia, and for twelve years if they are established in Asia”. Finally, the migrant families would be asked to inform the Ottoman consuls at least two months in advance so that the government would complete preparatory steps before the migrants' arrival. ${ }^{74}$

The result of Oliphant's second and last initiative to get official permission for Jewish migration to Palestine was extremely disappointing for him and for thousands of Romanian and Russian Jews who had high expectations of his initiatives. Equally disappointing was the fact that in London he had been accused

73 Wallace to Frelinghuysen, Constantinople, no. 107, 11 July 1882, in Papers Relating to the Foreign Relations, p. 517.

74 For the full translation of the Ottoman law of immigration see, Papers Relating to the Foreign Relations, pp. 519-520. 


\section{Ş. TUFAN BUZPINAR}

of spending the money set aside for refugees for his own luxury life in Istanbul. ${ }^{75}$ This time, his position was weaker than it had been two years ago for the simple reason that the Ottoman government introduced new regulations to welcome all migrants including the Jewish ones on certain conditions that were very hard to refuse. Secondly, he was in a much weaker position in the summer of 1882 for the Egyptian crisis had reached its peak. Finally, the British occupation of Egypt in September 1882 ended all expectations that Oliphant might have still had. Not surprisingly, Oliphant left Istanbul for Beirut in the same month without making any progress in his scheme of Jewish restoration to Palestine.

\section{IV}

In conclusion, Oliphant devoted the last decade of his life to the question of Jewish settlement in Palestine. He was born into a family whose evangelical convictions had a deep impact on his religio-political views and activities. Although he had been familiar with restorationist ideas and with Jewish ideas of returning to Palestine for some decades, Oliphant did not make it a primary object of his life until 1878. Many developments in that year, some personal and religious, others political and international, led him to devote the rest of his life to the restoration of Jews to Palestine.

Oliphant's proposal of 1879 regarding Jewish settlements in Palestine was unique in several respects. Firstly, it was the first and the only written proposal submitted to the Ottoman government. It was well prepared, articulated and based on solid ground work in Palestine. Thirty-seven articles in total covered almost all aspects of the envisaged sample administration that was to be established in the Balka region. Secondly, it predated the Zionist initiatives in the second half of the 1890s at the Porte by almost two decades. Thirdly, by receiving such a well-prepared proposal, Abdülhamid's government had, for the first time, an opportunity to discuss an issue which was to be repeatedly on agenda until the end of the Ottoman state. In other words, Oliphant provided a valuable opportunity for the Sultan to become aware of the Palestine question so early in his reign, assess its different aspects, and finally develop his policies regarding the region in question. The Ottoman position regarding this question was clear and consistent:

75 For details of accusations, see Taylor, Laurence, p. 213; For an examination of his financial sources see, Thomas Amit, "Laurence Oliphant: Financial Sources for His Activities in Palestine in the 1880s", Palestine Exploration Quarterly, 139/3 (2007), pp. 205-212. 
The Jewish migrants were to be welcomed on the condition that they would be settled in designated areas in Anatolia and Rumelia and would be subject to Ottoman laws in action. It was also made clear that they were not to be allowed to settle in Syria or Palestine.

As for Oliphant, his position was also clear and consistent. Inspired by his belief in the prophecy that the second coming of Jesus Christ required Jewish restoration to Palestine, he devoted his time and energy during the last decade of his life to the realization of that goal. During the three years of his endeavours to get Ottoman permission for Jewish settlements in Palestine, Oliphant time and again shared his views about the prophecy with diplomats and statesmen, even with members of the Ottoman cabinet. When he faced stern refusals from the Ottoman government, he decided to settle in Haifa in Palestine in order to contribute to his goal at least on a personal level. Finally, it should be underlined that Oliphant's efforts made enormous contributions to the increase in awareness of the question of Jewish settlement in Palestine, not only in Istanbul but also in countries like Romania, the United Kingdom and the United States.

Abstract $~$ This paper focuses on Laurence Oliphant's efforts to organize a Jewish settlement in Palestine between 1879 and 1882 and the Ottoman response to these efforts. After giving due information about Oliphant's Restorationist (Christian Zionist) background in order to understand why he was so deeply interested in the question of Jewish settlement in Palestine, his proposal to the Ottoman government in 1879 on this issue is explained in some detail, based primarily on Ottoman archival documents. This is the only instance in which the Ottoman government was officially faced with the issue of Jewish settlement in Palestine, and was also the first instance in which it was discussed at the highest level, resulting in a response that guided Ottoman policies during the rest of Abdülhamid II period.

The following part of the article examines Oliphant's second attempt at obtaining permission for a Jewish settlement in Palestine in 1882. In this part, American support for Oliphant's efforts, as well as the Ottoman reaction to this support, will be explained. The Ottoman response to the question of Jewish settlement in Palestine constitutes an important component of the article.

Keywords: Abdülhamid II, Laurence Oliphant, Christian Zionism, Jewish migration to Palestine, Palestine Question. 


\section{Bibliography}

\section{Archival Documents}

BOA, İrade Mesâil-i Mühimme (İ. MMS.), 35/1006.

BOA, Yıldız Perakende Evrakı Yaveran ve Maiyyet-i Seniyye Erkan-1 Harbiye Dairesi (Y. PRK. MYD.), 1/47.

BOA, Yıldız Perakende Evrakı Hariciye Nezareti Maruzatı (Y. PRK. HR.), 5/54.

BOA, Yıldız Perakende Evrakı, Başkitabet Dairesi Maruzatı (Y. PRK. BŞK.), 3/7.

BOA, Yıldız Sadaret Resmi Evrakı (Y. A. RES.), 5/58.

BOA, Hariciye Nezareti, Tahrirat-1 Hariciye Odası (HR.TH.), 35/38/1.

BOA, Hariciye Nezareti, Tahrirat-1 Hariciye Odası (HR.TH.), 35/38/2.

BOA, Hariciye Nezareti, Tahrirat-1 Hariciye Odası (HR.TH.), 35/38/3.

BOA, Babıali Evrak Odası Amedi Kalemi Defterlerinden Meclis-i Vükela Aynen Kayıt Defteri, no. 222.

BOA, İrade Meclis-i Mahsus (İ. MMS.), 3114.

BOA, Yıldız Tahrirat-1 Ecnebiye ve Mabeyn Mütercimliği (Y. PRK. TKM.), 3/20.

The National Archives (TNA), Foreign Office (FO), 78/2989 Eldridge to Salisbury, Beirut 14 May 1879.

TNA, FO, 78/3086 no. 493, Layard to Granville, confidential letter, Therapia 10 May 1880.

\section{Newspapers}

The Times, 15 February 1882.

\section{Secondary Sources}

Amit, Thomas: "Laurence Oliphant: Financial Sources for His Activities in Palestine in the 1880s", Palestine Exploration Quarterly, 139/3 (2007), pp. 205-212.

Beydilli, Kemal: "II. Abdülhamit Devrinde Gelen İlk Alman Askeri Heyeti Hakkında", IÜEF Tarih Dergisi, XXXII (1979), pp. 481-493.

Buzpınar, Ş. Tufan: "II. Abdülhamid Döneminin İlk Yıllarında Filistin'de Yahudi İskan Girişimleri (1879-1882), Türkiye Günlüğ̈̈, 30 (Eylül-Ekim 1994), pp. 58-65.

Casey, Bart: The Double Life of Laurence Oliphant, New York: Posthill Press 2015.

Cazalet, Edward: The Berlin Congress and the Anglo-Turkish Convention, London: Edward Stanford 1878.

Cazalet, Edward: The Eastern Question, London: Edward Stanford 1878.

Çetinsaya, Gökhan: "II. Abdülhamid'in İç Politikası: Bir Dönemlendirme Denemesi", Journal of Ottoman Studies, XLVII (İstanbul 2016), pp. 353-409. 
Epstein, Lawrence J: Zion's Call: Christian Contributions to the Origins and Development of Israel, New York: University Press of America 1984.

Hansard Parliamentary Debates, 1881, Vol. 258, $3^{\text {rd }}$ Series.

Henderson, Philip: The Life of Laurence Oliphant, London: Robert Hale Limited 1956.

Keith, Alexander: The Land of Israel According to the Covenant with Abraham, with Isaac and with Jacob, New York: Harper and Brothers 1844.

Kuneralp, Sinan (ed.): The Private Letters of Sir Austen Henry Layard during His Constantinople Embassy 1877-1880, Istanbul: The Isis Press, 2018.

Lewis, Donald M.: The Origins of Christian Zionism: Lord Shaftesbury and Evangelical Support for a Jewish Homeland, Cambridge: Cambridge University Press 2013.

Loewe, L. (ed): Diaries of Sir Moses and Lady Montefiore, II, Chicago: Belford-Clark Co. 1890.

Moruzzi, Norma Claire: "Strange Bedfellows: The Question of Lawrence Oliphant's Christian Zionism”, Modern Judaism, 26/1 (February 2006), pp. 55-73.

Oliphant, Laurence: The Land of Gilead with Excursions in the Lebanon, Edinburgh and London: William Blackwood and His Sons 1880.

Oliphant, Laurence: The Trans-Caucasian Campaign of the Turkish Army under Omer Pasha: A Personal Narrative, Edinburgh and London: William Blackwood and His Sons 1856.

Oliphant, Margaret: Memoir of the Life of Laurence Oliphant and of Alice Oliphant, His Wife, Vol. II, New York: Harper \& Brothers 1891.

Papers Relating to the Foreign Relations of the United States, December 4, 1882, Washington: Government Printing Office 1883.

Pragai, Michael J.: Faith and Fulfilment: Christians and the Return to the Promised Land, London 1985.

Sizer, Stephen: Christian Zionism: Road Map to Armageddon?, Nottingham: Inter-Varsity Press 2010.

Taylor, Anne: Laurence Oliphant (1829-1888), Oxford: Oxford University Press 1982.

Tellioğlu, Ömer: Filistin'e Musevi Göçü ve Siyonizm, İstanbul: Kitabevi Yayınları 2015.

Tuchman, Barbara W.: Bible and Sword: England and Palestine from the Bronze Age to Balfour, New York: Random House Trade Paperback Edition 2014.

Yasamee, Feroze A.K.: Ottoman Diplomacy: Abdülhamid II and the Great Powers, 18781888, İstanbul: The Isis Press 1996.

Yavuz, M. Hakan \& Sluglett, Peter (eds.): War and Diplomacy: The Russo-Turkish War of 1877-1878 and the Treaty of Berlin, Salt Lake City: The University of Utah Press 2011. 